doi: https://doi.org/10.15407/dopovidi2017.10.048

УДК 517.58/.5892
A.N. Timokha ${ }^{1,2}$, I.A. Raynovskyy ${ }^{1}$
${ }^{1}$ Institute of Mathematics of the NAS of Ukraine, Kiev
${ }^{2}$ Centre of Excellence "Autonomous Marine Operations and Systems",
Norwegian University of Science and Technology, Trondheim, Norway
E-mail: tim@imath.kiev.ua, ihor.raynovskyy@gmail.com

\title{
The damped sloshing in an upright circular tank due to an orbital forcing
}

Presented by Corresponding Member of the NAS of Ukraine A.N. Timokha

The nonlinear Narimanov-Moiseev-type modal system with linear damping terms is employed to study the damped steady-state resonant sloshing in an upright circular tank due to a prescribed horizontal orbital (elliptic) tank motion with the forcing frequency close to the lowest natural sloshing frequency. Whereas the undamped sloshing implies coexisting the co-directed (with forcing) and counter-directed angular progressive waves (swirling), the damping makes the counter-directed swirling impossible as the forcing orbit tends to a circle.

Keywords: sloshing, damping, steady-state waves.

An upright circular cylindrical rigid tank performs a small-magnitude prescribed periodic horizontal motion, which is described by the two generalized coordinates $r_{0} \eta_{1}(t)$ and $r_{0} \eta_{2}(t)$ ( $r_{0}$ is the tank radius) as shown in fig. 1. Those tank motions are relevant for bioreactors [1]. In contrast to industrial containers whose dimensions are relatively large, the bioreactors have $r_{0} \approx 5-10[\mathrm{~cm}]$ that requires accounting for the damping associated with a laminar boundary layer and the bulk viscosity.

The problem is studied in the nondimensional statement provided by the characteristic size $r_{0}$ and time $1 / \sigma$, where $\sigma$ is the forcing frequency close to the lowest natural sloshing frequency $\sigma_{11}$. The nondimensional forcing magnitude is small, i.e. $\eta_{i}(t)=O(\varepsilon), i=1,2$. Fig. 1 illustrates the adopted nomenclature. The unknowns, $\varsigma$ and $\Phi$ (the velocity potential), are defined in the tank-fixed coordinate system and can be found from either the corresponding free-surface problem or its equivalent variational formulation. Using the Fourier-type representation (in the cylindrical coordinates)

$$
\varsigma(r, \theta, t)=\sum_{M, i}^{\infty} J_{M}\left(k_{M i} r\right) \cos (M \theta) p_{M i}(t)+\sum_{m, i}^{\infty} J_{m}\left(k_{m i} r\right) \sin (m \theta) r_{m i}(t)
$$

makes it possible to derive an approximate system of ordinary differential equations (nonlinear modal equations [2]) with respect to the free-surface generalized coordinates $p_{M i}(t)$ 
Fig. 1. The domain $Q(t)$ is confined by the free surface $\Sigma(t)(z=\varsigma(r, \theta, t))$ and the wetted tank surface $S(t)$. Sloshing is considered in the tankfixed coordinate system $O x y z$ whose coordinate plane $O x y$ coincides with the mean (hydrostatic) free surface $\Sigma_{0} ; O z$ is the symmetry axis. Smallmagnitude periodic tank excitations are governed by generalized coordinates $\eta_{1}(t)$ (surge) and $\eta_{2}(t)$ (sway)

and $r_{m i}(t)$; here, $J_{M}(\cdot)$ is the Bessel functions of the first kind, $k_{M i}$ are the radial wave numbers $\left(J_{M}^{\prime}\left(k_{M i}\right)=0\right)$, and $\sigma_{M i}=\sqrt{k_{M i} \tanh \left(k_{M i} h\right) g / r_{0}}$ are the dimensional natural sloshing frequencies ( $g$ is the gravity acceleration).

Furthermore, the nonlinear Narimanov-Moiseev-type mo-

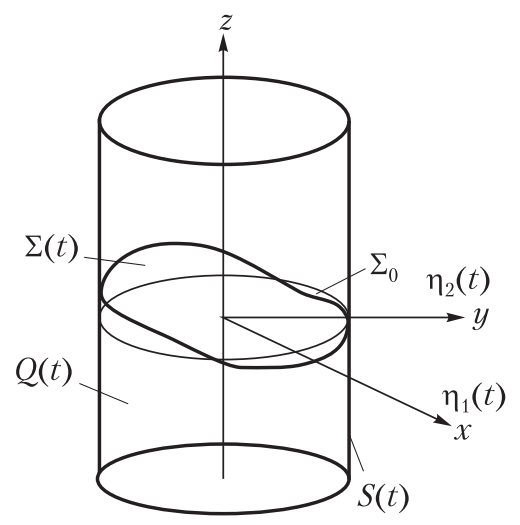
dal system [2] (the infinite-dimensional system of ordinary differential equations with respect to $p_{M i}(t)$ and $\left.r_{m i}(t)\right)$ is equipped with the linear damping terms $2 \xi_{M i} \bar{\sigma}_{M i} \dot{p}_{M i}$ and $2 \xi_{M i} \bar{\sigma}_{M i} \dot{r}_{M i}$, where the damping coefficients $\xi_{M i}$ are taken according to the formula by Miles [3], which provides a rather accurate theoretical prediction of the logarithmic decrements of the natural sloshing modes due to the boundary layer and the bulk viscosity. The $2 \pi$-periodic solutions of the modified modal system describe the resonant steady-state sloshing. To find the asymptotic steady-state solutions, we use the Bubnov-Galerkin procedure [2, 4] by posing the lowest-order components of the primary resonantly excited modes as

$$
p_{11}(t)=a \cos t+\bar{a} \sin t+O(\varepsilon), r_{11}(t)=\bar{b} \cos t+b \sin t+O(\varepsilon)
$$

where the nondimensional amplitudes $a, \bar{a}, \bar{b}$, and $b$ are of $O\left(\varepsilon^{1 / 3}\right)$. Having known these amplitudes approximates the steady-state free-surface elevations as the superposition of the two out-of-phase angular modes

$$
\varsigma(r, \theta, t)=J_{1}\left(k_{11} r\right)[(a \cos \theta+\bar{b} \sin \theta) \cos t+(\bar{a} \cos \theta+b \sin \theta) \sin t]+O\left(\varepsilon^{1 / 3}\right),
$$

which implies the so-called swirling (angular progressive wave) unless $(a \cos \theta+\bar{b} \sin \theta)$ and $(\bar{a} \cos \theta+b \sin \theta)$ are congruent patterns $(\Leftrightarrow a b=\overline{a b})$. The latter means that $(3)$ determines a standing wave. Occurrence of swirling and standing waves was in many details discussed in $[2,4-6]$.

The Bubnov-Galerkin procedure leads to a necessary solvability condition with respect of $a, \bar{a}, \bar{b}$, and $b$ appearing as a system of nonlinear algebraic equations $[2,4,5]$. To describe the steady-state sloshing, we should solve the system for any $\bar{\sigma}_{11}=\sigma_{11} / \sigma$ close to 1 . The first Lyapunov method can be used to study the stability. The algebraic system is rederived in terms of the integral amplitudes A, B (the main wave elevation components in the $O x$ and $O y$ directions, respectively) and the phase-lags $\psi, \varphi$ :

$$
\begin{aligned}
& A=\sqrt{a^{2}+\bar{a}^{2}} \text { and } B=\sqrt{b^{2}+\bar{b}^{2}} \\
& a=A \cos \psi, \quad \bar{a}=A \sin \psi, \bar{b}=B \cos \varphi, \bar{b}=B \sin \varphi,
\end{aligned}
$$



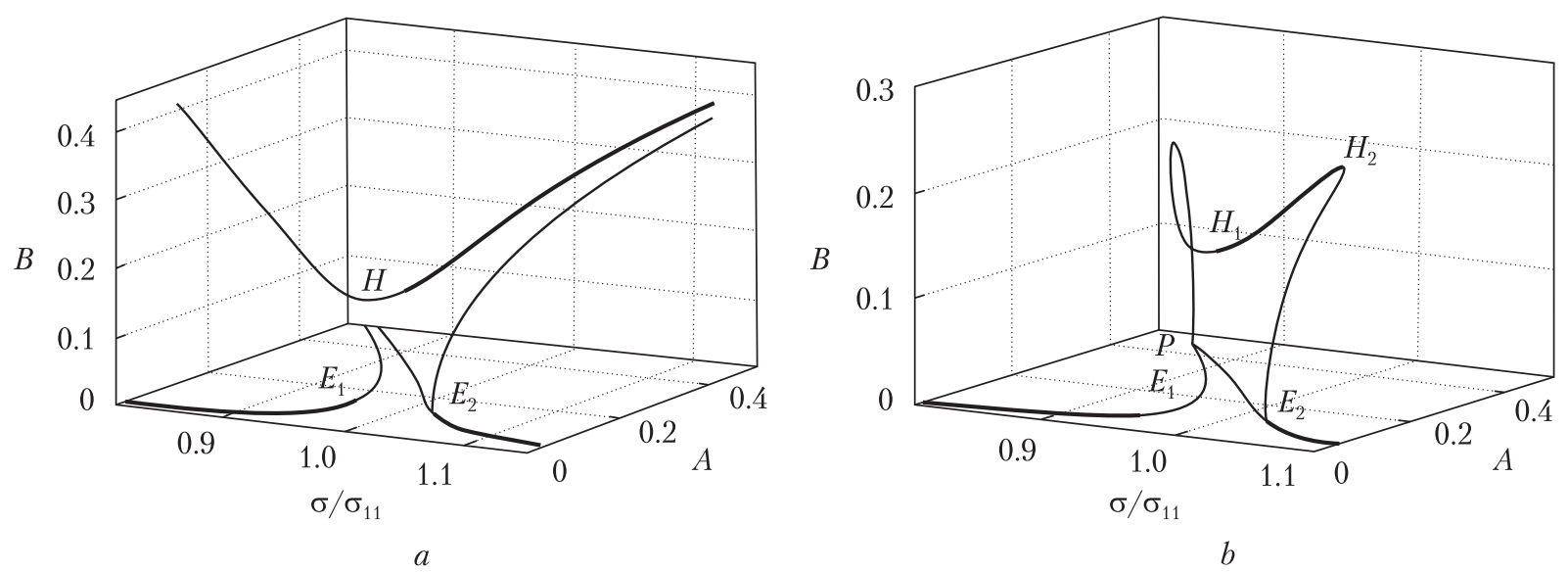

Fig. 2. Response curves in the $\left(\sigma / \sigma_{11}, A, B\right)$-space for the longitudinal $(\varepsilon=0)$ harmonic forcing in the $O x z$-plane, $h / r_{0}=1.5$, the nondimensional forcing amplitude $\eta_{1 a}=0.01\left(\eta_{2 a}=0\right)$. The undamped sloshing $(\xi=0)$ is presented in $(a)$ and the damped case $(\xi=0.02)$ is shown in $(b)$. There is no stable steady-state sloshing between $E_{1}$ and $E_{2}$, where irregular (chaotic) waves are expected. Curves on (close to) the $\left(\sigma / \sigma_{11}, A\right)$-plane correspond to the (almost) planar wave regime

$$
\begin{aligned}
& \left\{\begin{array}{l}
A\left[\bar{\sigma}_{11}^{2}-1+m_{1} A^{2}+\left(m_{3}-F\right) B^{2}\right]=\varepsilon_{x} \cos \psi ; \quad A\left[D B^{2}+\xi\right]=\varepsilon_{x} \sin \psi ; \\
B\left[\bar{\sigma}_{11}^{2}-1+m_{1} B^{2}+\left(m_{3}-F\right) A^{2}\right]=\varepsilon_{y} \sin \varphi ; \quad B\left[D A^{2}-\xi\right]=\varepsilon_{y} \cos \varphi ;
\end{array}\right. \\
& \left\{\begin{array}{l}
F=\left(m_{3}-m_{1}\right) \cos ^{2}(\alpha)=\left(m_{3}-m_{1}\right) /\left(1+C^{2}\right), \\
D=\left(m_{3}-m_{1}\right) \sin (\alpha) \cos (\alpha)=\left(m_{3}-m_{1}\right) C /\left(1+C^{2}\right),
\end{array}\right.
\end{aligned}
$$

where $\alpha=\varphi-\psi, C=\tan \alpha, 0 \leqslant \varepsilon_{y} \leqslant \varepsilon_{x} \neq 0, F(\alpha)$ and $D(\alpha)$ are $\pi$-periodic functions of the phase-lags difference $\alpha$, and $\varepsilon_{x}, \varepsilon_{y}$ are linear functions of the forcing amplitudes $\eta_{1 a}, \eta_{2 a}$ The coefficients $m_{1}$ and $m_{2}$ are known functions of the liquid depth (see, [2, 4]) but $\xi=2 \xi_{11}$ (damping rate of the two lowest natural sloshing modes). A special numerical scheme [7] was developed to solve (5), i.e. to describe how the main wave amplitude components $A$ and $B$ change versus $\sigma / \sigma_{11}$.

The undamped resonant steady-state sloshing due to longitudinal excitations along the $O x$ axis $\left(\varepsilon_{x}>0, \varepsilon_{y}=0, \xi=0\right)$ was analyzed in [2, 4]. A planar standing wave and the swirling are identified. In terms of (4) and (5) with $\xi=0$ these imply $B=0, \sin \psi=0, C=0$, and $A B \neq 0, \sin \psi=\cos \varphi=0, \quad(C= \pm \infty)$, respectively. The swirling consists of two identical angular progressive waves occurring in either counter- or clockwise directions, they correspond to $C=+\infty$ and $-\infty$ respectively. Fig. 2, $a$ presents the corresponding response curves. Case $(b)$ shows the linear damping effect with $\xi=0.02$ The branches belonging (close) to the plane $\sigma / \sigma_{11}, A$ are responsible for the (almost) planar standing wave regime. The regime is stable to the left of $E_{1}$ and to the right of $E_{2}$. It becomes unstable in a neighborhood of the primary resonance $\sigma / \sigma_{11}=1$, where the stable swirling (to the right of $H\left(H_{1}\right)$ ) and irregular waves (the steady-state sloshing is unstable) between $E_{1}$ and $H\left(H_{1}\right)$ are predicted. The damping removes infinite points on the response curves of $(a)$, so that the steady-state swirling branching in $(b)$ constitutes an arc pinned 

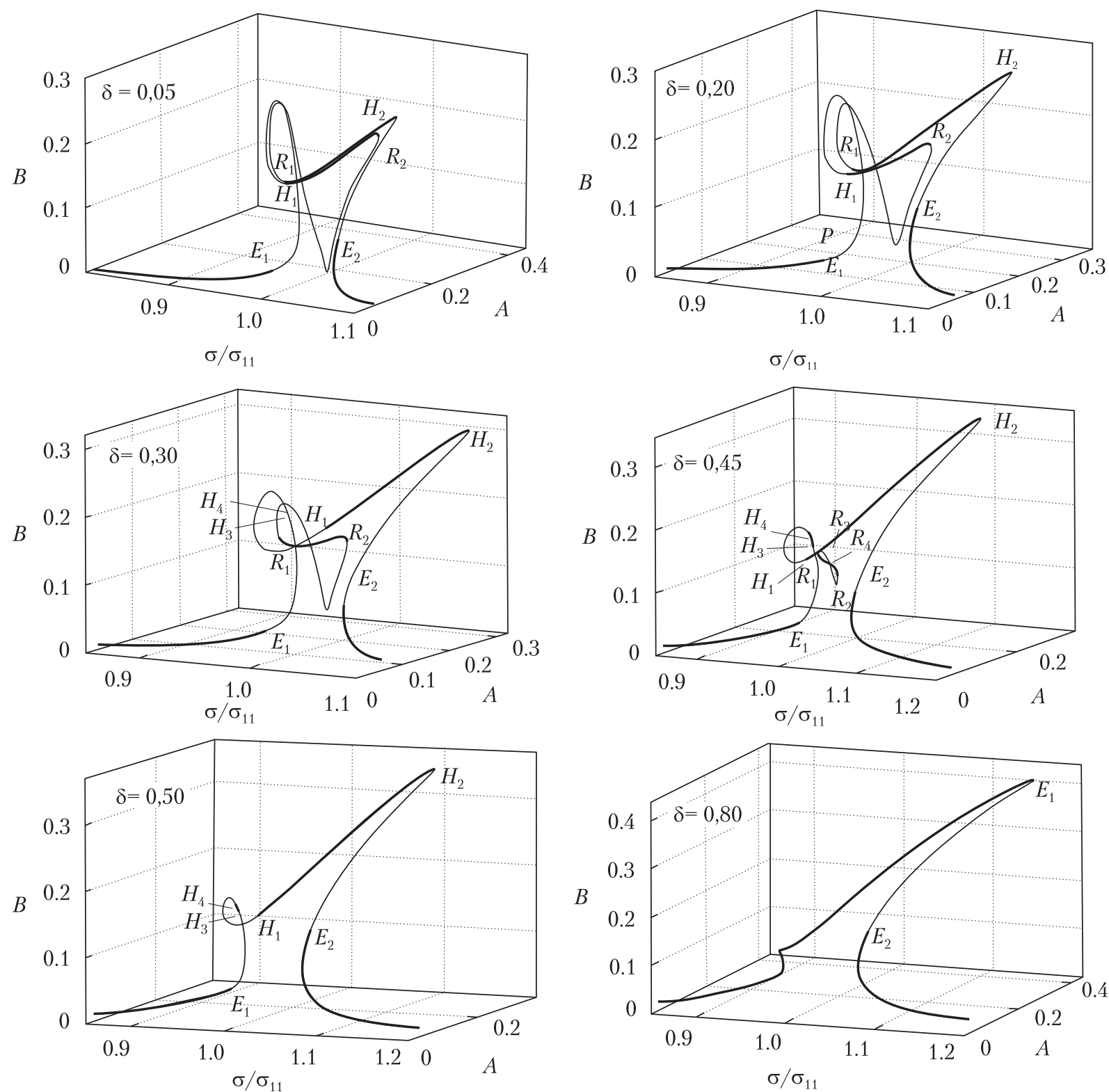

Fig. 3. Response curves for $\delta=\varepsilon_{y} / \varepsilon_{x}>0$ in the $\left(\sigma / \sigma_{11}, A, B\right)$-space. The steady-state resonant sloshing is due to an elliptic counterclockwise forcing with $\eta_{1 a}=0.01, \eta_{2 a}=\delta \eta_{1 a} ; \xi=0.02$. All the points on the response curves correspond to the swirling. The bold lines mark the stability

at $E_{2}$ and $P$, which can be treated as bifurcation points, where the swirling emerges from the (almost) planar steady-state wave regime.

In [5], we showed that any orbital small-magnitude periodic tank motions are equivalent, to within the higher-order terms, to an artificial elliptic-type horizontal excitation with $\varepsilon_{y}=\delta \varepsilon_{x}$, $0<\delta \leqslant 1$. How the response curves of the damped steady-state sloshing change with increasing $\delta$ is shown in Fig. 3. When $\delta \neq 0$, all the steady-state sloshing regimes are of the swirling type. Specifically, there are no identical swirling waves with opposite directions, as it has been in the 
longitudinal case (each point on $\mathrm{PH}_{1} \mathrm{H}_{2} \mathrm{E}_{2}$ in Fig. 2, $b$ implies the pair of these waves). The connected branching in Fig. 2, $b$ splits into the response curve $E_{1} H_{1} H_{2} E_{2}$ existing for any $\sigma / \sigma_{11}$ and $0<\delta \leqslant 1$ and corresponding to the co-directed (with the counterclockwise elliptic forcing) angular progressive waves and the loop-like branch with $R_{1}$ and $R_{2}$ whose points imply the counter-directed swirling. Fig. 3 shows that the latter branch disappears, as $\delta$ increases. This is a very interesting fact, which contradicts the steady-state analysis of the undamped sloshing in [2], where both the co- and counter-directed angular progressive waves exist and can be stable in certain frequency ranges for any $0<\delta \leqslant 1$.

In summary, the linear viscous damping matters for the orbitally-excited sloshing in bioreactors of an upright circular cylindrical shape. It affects qualitatively and quantitatively the steady-state sloshing and the corresponding response curves. The most interesting fact is that the damping, even being relatively small, makes the counter-directed angular progressive waves (swirling) impossible, as the forcing orbit tends to a circle. This fact contradicts the the undamped steady-state analysis, but it is qualitatively consistent with model tests by M. Reclari in [1].

The first author acknowledges the financial support of the Centre of Autonomous Marine Operations and Systems (AMOS) whose main sponsor is the Norwegian Research Council (Project No. 223254--AMOS).

\section{REFERENCES}

1. Reclari, M. (2013). Hydrodynamics of orbital shaken bioreactors (PhD Thesis, No. 5759). Ecole Polytechnique Federale de Lausanne, Suisse.

2. Faltisen, O. M., Lukovsky, I. A. \& Timokha, A. N. (2016). Resonant sloshing in an upright tank. J. Fluid Mech., 804, pp. 608-645.

3. Miles, J. W. (1998). A note on interior vs. boundary-layer damping of surface waves in a circular cylinder. J. Fluid Mech., 364, pp. 319-323.

4. Lukovsky, I. A. (2015). Nonlinear dynamics: Mathematical models for rigid bodies with a liquid. Berlin: De Gruyter.

5. Raynovskyy, I. \& Timokha, A. (2016). Resonant liquid sloshing in an upright circular tank performing a periodic motion. J. Numer. Appl. Math., No. 2(122), pp. 71-82.

6. Royon-Lebeaud, A., Hopfinger, E. \& Cartellier, A. (2007). Liquid sloshing and wave breaking in circular and square- base cylindrical containers. J. Fluid Mech., 577, pp. 467-494.

7. Faltisen, O. M. \& Timokha, A. N. (2017). Resonant three-dimensional nonlinear sloshing in a square-base basin. Part 4. Oblique forcing and linear viscous damping. J. Fluid Mech., 822, pp. 139-169.

Received 26.06.2017

\section{O.M. Tимоха ${ }^{1,2}$, I.A. Райновський ${ }^{1}$}

${ }^{1}$ Інститут математики НАН України, Київ

2 Центр досконалості “Автономні морські операції та системи”,

Норвезький університет природничих та технічних наук, Трондхейм, Норвегія

E-mail: tim@imath.kiev.ua, ihor.raynovskyy@gmail.com

ХЛЮПАННЯ ІЗ ДЕМПФУВАННЯМ

У ВЕРТИКАЛЬНОМУ ЦИЛІНДРИЧНОМУ БАКУ

ПРИ ОРБІТАЛЬНИХ ЗБУРЕННЯХ

3 використанням нелінійної модальної системи Наріманова-Мойсеєва з лінійним демпфуванням вивчається затухаюче усталене хлюпання рідини у вертикальному круговому баку при заданому горизонтальному орбітальному (еліптичному) русі посудини з вимушеною частотою, близькою до власної частоти 
коливань. Тоді як випадок без демпфування включає як співнапрямлені (із напрямком орбітального руху), так і протилежно напрямлені кутові прогресивні хвилі, демпфування робить неможливим існування протилежно направленої хвилі при збуреннях, близьких до кругових.

Ключові слова: хлюпання рідини, демпфування, усталені хвилі.

\section{А.Н. Тимоха ${ }^{1,2}$, И.А. Райновский ${ }^{1}$}

${ }^{1}$ Институт математики НАН Украины, Киев

2 Центр совершенства “Автономные морские операции и системы”, Норвежский университет естественных и технических наук, Трондхейм, Норвегия E-mail: tim@imath.kiev.ua, ihor.raynovskyy@gmail.com

\section{ПЛЕСКАНИЕ С ДЕМПФИРОВАНИЕМ В ВЕРТИКАЛЬНОМ ЦИЛИНДРИЧЕСКОМ БАКЕ ПРИ ОРБИТАЛЬНЫХ ВОЗБУЖДЕНИЯХ}

С использованием нелинейной модальной системы Нариманова-Моисеева с линейным демпфированием изучается затухающее установившееся плескание жидкости в вертикальном круговом баке при заданном горизонтальном орбитальном (эллиптическом) движении сосуда с вынужденной частотой, близкой к собственной частоте колебаний жидкости. В то время как случай без демпфирования включает как сонаправленные (с направлением орбитального движения), так и противоположно направленные угловые прогрессивные волны, демпфирование делает невозможным существование противоположно направленной волны при возбуждениях, близких к круговым.

Ключевые слова: плескание жидкости, демпфирование, установившиеся волны. 